\title{
Is Terrorism the Result of Root Causes such as Poverty, Oppression and Exclusion?
}

\author{
Dr. Chandima Daskon \\ National Centre for Peace and Conflict Studies, New Zealand \\ cdaskon@gmail.com
}

\begin{abstract}
Terrorism and poverty are serious socio-political problems that have been with us throughout the ages. Seemingly, a clear relationship does exist between poverty and terrorism, but is terrorism caused by poverty or is it the other way around. Regardless, it can be argued that fulfilment of basic human needs would make this world a more secure place for all its citizens. This article examines whether terrorism is the result of root causes such as poverty, oppression and exclusion, based on a critical review of the existing literature on the subject. With an understanding of poverty as an influential social condition linked to terrorism, the essay will draw two main discussions for and against the statement - Is terrorism the result of root causes such as poverty, oppression and exclusion?
\end{abstract}

\section{INTRODUCTION}

"No one in this world can be comfortable or safe when so many people are suffering and deprived"

\section{UN Secretary-General Kofi Annan ${ }^{1}$}

Terrorism and poverty are serious socio-political problems that have been with us throughout the ages. But in the modern period we see different trends and characters developing with both terrorism and poverty. The Global Terrorism Index (GTI) measures terrorism as a global phenomenon and, as recorded in 2013, 80 percent of global deaths from terrorist attacks occurred in five countries, (Iraq, Afghanistan, Pakistan, Nigeria and Syria). ${ }^{2}$ Poverty is another catastrophic phenomenon, causing extreme suffering from a lack of basic human needs. According to the World Bank, more than three billion people in the world live on less than $\$ 2.50$ per day. ${ }^{3}$ Poverty has killed an estimated 270 million people since 1990 and, fifty thousand people die from poverty-related causes everyday (Piazza, 2010:37). ${ }^{4}$ In a closer look, the countries with higher incidents of terrorist attacks apparently suffer from higher levels of poverty. For example, in Iraq, 20 percent of the population lives below the poverty line. ${ }^{5}$ Afghanistan remains the most impoverished country in Asia with 30 percent of its population living below the poverty line. ${ }^{6}$ More than half of the population of Pakistan lives below the poverty line. ${ }^{7}$ According to the BBC, in Nigeria almost 100 million people live on less than $\$ 1$ a day. Most strikingly, the war in Syria has plunged 80 percent of that country's population into poverty. ${ }^{9}$

\footnotetext{
${ }^{1}$ Piazza ,J.A.(2007). Global poverty, inequality and transnational terrorism: Retrieved from, http://www.terroris manalysts.com/pt/index.php/pot/article/view/16/html

${ }^{2}$ Institute for Economics and Peace, (2014). Global Terrorism Index 2014: Retrieved from, http:// www.visionofhumanity.org/sites/default/files/Global\%20Terrorism\%20Index\%20Report\%202014_0.pdf

${ }^{3}$ Poverty facts and stats: Retrieved from,http://www.globalissues.org/article/26/poverty-facts-and-stats

${ }^{4}$ Piazza, J.A. (2010).Poverty is a weak causal link, In Gottlieb (ed.) Debating terrorism and counterterrorism

${ }^{5}$ Iraq - over twenty five percent of Iraqis live under poverty: Retrieved from, http://www.irinnews.org/ report/84526/iraq-over-20-percent-of-iraqis-live-below-the-poverty-line

${ }^{6}$ Poverty in Afghanistan: Retrieved from, http://borgenproject.org/poverty-in-afghanistan/

${ }^{7}$ Over half of Pakistan lives under poverty line: Retrieved from, http://www.dawn.com/news/1110248

${ }^{8}$ Nigerians living in poverty rise to nearly $61 \%$ : Retrieved from, http://www.bbc.com/news/world-africa-17 015 873

${ }^{9}$ Syria's war: Retrieved from, http://www.theguardian.com/world/2015/mar/12/syrias-war-80-in-poverty-lifeexpectancy-cut-by-20-years-200bn-lost
} 


\section{Dr. Chandima Daskon}

Seemingly, a clear relationship does exist between poverty and terrorism, but is terrorism caused by poverty or is it the other way around. Regardless, it can be argued that fulfilment of basic human needs would make this world a better, safer and more secure place for all its citizens. With respect to the relationship between terrorism and poverty, the United Nations, for instance, supports the belief that terrorism is a predictable consequence of poverty, and inequality of wealth and resource distribution. However, the 2014 GTI considers that poverty and other economic factors are less relevant and have little explanatory power as to the onset of terrorism. ${ }^{10}$ In academia, there is much debate highlighting the importance of alleviating poverty and marginalisation as the best possible ways of responding to terrorism. From this perspective, terrorism and poverty are correlated and the relationship is justified to a great extent. However, this does not necessarily mean there is a direct or linear relationship between poverty and terrorism.

As a fundamental social phenomenon, terrorism occurs for different reasons in different contexts. Terrorism is caused by complex and interrelated social, economic, cultural, political, historical and environmental factors. Therefore, the onset of terrorism cannot be studied through a linear model or simply by cause and effect analysis. In fact, 'what causes terrorism?' may not be the right question to ask, as it might never be able to be answered. What is terrorism? What are the conditions in which terrorism is most likely to take place? Is poverty a favourable condition for terrorism? ${ }^{11}$ These questions might provide a critical approach to the problem of causality, while appreciating more complex relationships among contributing factors. Regardless of such considerations, poverty and terrorism remain the biggest threats and greatest barriers to a peace and prosperous life for many, and both issues deserve a clear, fact-based critical assessment.

Against this background, this article examines whether terrorism is the result of root causes such as poverty, oppression and exclusion, based on a critical review of the existing literature on the subject. With an understanding of poverty as an influential social condition linked to terrorism, the essay will draw two main discussions for and against the statement - Is terrorism the result of root causes such as poverty, oppression and exclusion? Understanding poverty as an influential social condition, the essay critically discusses the above statement based on three fundamental questions of terrorism studies: why does terrorism occur? how does the process of terrorism work? and; what are the social and political effects of terrorism? (Crenshaw, 1981). ${ }^{12}$ Before proceeding, the following section briefly explains the concepts of terrorism and poverty. Without being more specific about these concepts, it is difficult to critically engage and understand the linkages between these two complicated and challenging social phenomenon.

\section{WHAT IS TERRORISM?}

Defining terrorism is problematic and there is no universally accepted definition of it. Despite this definitional problem, and questions over the analytical usefulness of the following, terrorism can be simply explained as an organised terror activity or strategic criminal violence or a tactic against people or property. Even though the idea of terrorism has been widely appreciated in early human societies, it had been a relatively contested and complex term, which is not clearly definable. Jackson $(2008)^{13}$ writes that misguided assumptions of terrorism are often problematic, 'not least because terrorism is a highly emotive and divisive concept which different scholars and societies have often understood in very different ways'. Krueger $(2007: 14)^{14}$, for example, replaces terrorism with the neutral term politically motivated violence, which aims "to spread fear". Richards (2014:230) ${ }^{15}$ asserts that terrorism 'is the use of violence or the threat of violence with the primary purpose of generating a psychological impact beyond the immediate victims or object of attacks for a political motive'. However, the term remains unbalanced, politically biased and highly limited in focus, and terrorism is

10 Institute for Economics and Peace, (2014). Global Terrorism Index 2014: Retrieved from, http:// www.visionofhumanity.org/sites/default/files/Global\%20Terrorism\%20Index\%20Report\%202014_0.pdf

${ }^{11}$ The causes of Terrorism: Retrieved from, http://terrorism.about.com/od/causes/a/causes_terror.htm

${ }^{12}$ Crenshaw, M. (1981). The causes of terrorism, Comparative Politics, Vol 13(4)379-399.

${ }^{13}$ Jackson, R. (2008).Perspectives on Terrorism: Retrieved from, http://www.terrorismanalysts.com/ pt/ index.php/pot/article/view/27/html

${ }^{14}$ Krueger, A. (2007). What Makes a Terrorist: Economics and the Roots of Terrorism, Princeton University Press. New Jersey.

${ }^{15}$ Richards, A., (2014). Conceptualizing Terrorism, Studies in Conflict \& Terrorism, 37(3): 213-236 
purely a discursively constructed and labelled phenomenon (Jackson 2011), and as Jackson $(2011: 117)^{16}$ writes, "terrorism is fundamentally a social fact rather than a brute fact...its wider cultural-political meaning and its descriptive status - as 'war', crime etc., is decided by socially negotiated agreement....involving various authorities...hence, 'terrorism' does not exist as an objective". Being aware that terrorism is a discursively constructed concept that presents problems in establishing definitions that are of analytical usefulness, this essay understands terrorism as a politically, ideologically and religiously or culturally induced threat/violence designed to achieve particular (someone else's) targets/aims, through extreme destruction and intimidation.

\section{WHAT IS POVERTY?}

As with terrorism, poverty suffers from inherent definitional problems. In its simplest form poverty entails the idea of inadequacy of financial resources to meet primary human necessities such as food, shelter, and clothing for survival with dignity. The World Bank defines poverty as a "pronounced deprivation in well-being that comprises many dimensions, such as, low income, inadequate access to basic goods and services, low level of health, education, inadequate physical security, lack of voice, and insufficient capacity and opportunity to better one's life". ${ }^{17}$ According to the United Nations, poverty is "the inability of getting choices and opportunities" and "a violation of human dignity". ${ }^{18}$ It means a lack of a basic capacity to participate effectively in society. Poverty entails insecurity, powerlessness, exclusion and susceptibility to violence. ${ }^{19}$ One of the underlying problems of poverty is the assumption that greater poverty equates with less political power. Imreet., al $(2008)^{20}$ writes that globalization forces poor people to try and change their circumstances and move into non-poverty conditions leading to all kinds of conflicts in which the struggle for power in nation-states in the "Global South can be directly related to their attempts to climb out of poverty". This essay understands that both poverty and terrorism show some inherent problems in relation to their definitions, the analytical usefulness of those definitions, context, and who defines why, for what, when and where? Existing knowledge and understanding both in terms of terrorism and poverty can function as a mode of dominance (see Jackson, et, al, 2011), and as Cox (1981:128) ${ }^{21}$ argues, 'theory is always for someone and for some purpose'. Hence, the essay attempts to provide a reasonable justification, which is neutral and impartial of external interests.

\section{YES, TERRORISM IS CAUSED BY POVERTY, OPPRESSION AND EXCLUSION}

"We fight poverty because hope is an answer to terror"-

(President Bush, 2002 at Montreal Development Summit, Kruger 2007:12)

The failure of human development and absence of peace may trigger social violence leading to terrorist activities. When people become deprived, oppressed and excluded from the mainstream development process by limiting their choices, opportunities and accessibility to basic human needs, it can induce social tension, corruption and violation by altering the social structure, thus enhancing opportunities for terrorism. Although it is challenging to empirically justify poverty as a major cause of terrorism, there are influential declarations and policy statements that justify the directcausality between poverty and terrorism. For example, Collin Powell, a former US Secretary of State (20012005), asserts "I fully believe that the root cause of terrorism does come from situations where there is poverty, where there is ignorance, where people see no hope in their lives". James Wolfensohn, President of the World Bank (1995-2005), declares that "....the disease is the discontent seething in Islam, and more generally, the world of poor" (Gottlieb, 2010:34-35). ${ }^{22}$ John Kerry's statement at a meeting with the Vatican's Secretary of State in 2014, declared, "We have a huge common interest in

\footnotetext{
${ }^{16}$ Jackson, R., et al.,(2011). Terrorism: A Critical Introduction, Palgrave and Macmillan, New York.

${ }^{17} \mathrm{http}: / /$ web.worldbank.org

${ }^{18}$ Gordon, D. (2005). Indicators of poverty and hunger: Retrieved from, http://www.un.org/esa/socdev/unyin/ documents/ydiDavidGordon_poverty.pdf

${ }^{19}$ ibid

${ }^{20}$ Imre, R. Moony, T.B, \&Clarke, B. (2008).Responding to Terrorism, political, philosophical and legal perspectives, Ashgate, England.

${ }^{21}$ Cox, R., (1981). Social Forces, States and World Orders: Beyond International Relations Theory, Millennium, Journal of International Studies, Vol 10(2), 126-155.

${ }^{22}$ Gottlieb, S.(2010). Debating terrorism and counterterrorism. SAGE,London.
} 


\section{Dr. Chandima Daskon}

dealing with this issue of poverty, which in many cases is the root cause of terrorism or even the root cause of the disenfranchisement of millions of people on this planet" (Sterman, 2015) ${ }^{23}$ In effect, poverty, income inequality and unemployment can be identified as key causes of terrorism. Politicians, policy experts and academic scholars suggest that poverty increases the likelihood of political coups and civil wars so conflating terrorism with poor economic conditions seems logical (Lozada, nd). ${ }^{24}$

There is some interesting empirical analysis that validates poverty as a root cause of terrorism. For example, Felter (2006) ${ }^{25}$ in his book, The making of a terrorist, argues that a lack of primary social welfare services, and extreme poverty and desperation, are important targets for terrorist recruitment and membership. Discussing the question 'can democracy stop terrorism? 'in Gause (2005:143),Halperin argues that "the roots of al Qaeda lie in the poverty and educational deficiencies of Saudi Arabia, Egypt, and Pakistan.... ${ }^{26}$ Based on a quantitative analysis, Hsieh and Pugh (1993) ${ }^{27}$ justify that poverty, unemployment and income inequality have contributed to higher violent crime rates According to Fearon and Laitin $(2003)^{28}$ unequal distribution of land and unequal access to material resources are principle causes of civil wars, armed ethnic and sectarian conflicts, and riots. For most of the countries at risk of civil war it is not so much due to their ethnic or religious characteristics, but rather the conditions that favour insurgency, mainly poverty and slow growth. ${ }^{29}$ Poverty and loss of livelihood opportunities help armed rebel movements and insurgencies with their recruitment efforts (Ohlsson, 2000) ${ }^{30}$ Arguingthat terrorism is a form of political violence, Gupta $(2012)^{31}$ believes that social structural imbalances, including poverty, poor education, income inequality and lack of political freedom, are causes of political violence and terrorism. Gupta further clarifies that frustrations and anger created by these unstable structures which prevent people reaching their full potential cause violent behaviour. Economic distress resulting from poverty contributes to military coups, regime collapse and the onset of nondemocratic rule (Gottlieb, 2010). Refugees and illegal migrants produced by poverty induced social upheavals have also been linked to violence and armed conflict (Zolberg and Benda, 2001). ${ }^{32}$

In her analysis, Von Hippel $(2010)^{33}$ argues that socioeconomic dynamics - poverty, exclusion and oppression - arean important cause of terrorism. For instance, she quotes' United Nations Secretary General Kofi Annan's declaration on the fight against poverty as being intrinsically linked to the fight against terrorism, and cites US President Bush's remark that "the extremists find their most fertile recruiting grounds in societies trapped in chaos and despair, places where people see no prospect of a better life". Von Hippel provides an interesting discussion with empirical justifications from different contexts. Referring to Islamist groups such as Al-Qaeda, Hezbollah in Lebanon and Hamas in Palestine, and the Muslim brotherhood movement in Egypt and Somalia's fundamentalism movement, she discusses the 'enabling environment' of terrorism. This enabling environment is created by economic incentives provided to poor communities by different sources such as direct aid, charity, social welfare services and humanitarian aid programmes, and has significantly fertilized terrorism.

\footnotetext{
${ }^{23}$ Sterman, D.(2015). Don't dismiss poverty's role in terrorism yet. Retrieved from http://time.com/3694305/ poverty-terrorism/

${ }^{24}$ Does poverty cause terrorism? Retrieved from, http://www.nber.org/digest/may05/w10859.html

${ }^{25}$ Felter, J. (2006). Recruitment for rebellion and terrorism in the Philippines. The Making of a Terrorist: Recruitment, Training, and Root Causes, volume 1, Praeger Security International.

${ }^{26}$ Shere W.(2007). The Struggle for peace

${ }^{27}$ Hsieh C.C., \& Pugh, M. D. (1993). Poverty, Income Inequality, and Violent Crime: A Meta- Analysis of Recent Aggregate Data Studies Criminal Justice Review,; 18; 182-202

${ }^{28}$ Fearon, J,\&Lsitin, D.(2003). Ethnicity, Insurgency and civil war, American Political Science Review, $97.75-$ 90.

${ }^{29}$ Ibid.

${ }^{30}$ Ohlsson, L,(2000).Livelihood conflicts: linking poverty and environment as causes of conflict. Retrieved from,https://www.staff.ncl.ac.uk/david.harvey/AEF806/OhlssonLivelihoods.pdf

${ }^{31}$ Gupta, D.K, Exploring roots of Terrorism. Retrieved from http://www-rohan.sdsu.edu/ dgupta/docs/ articles/RootCause.pdf

${ }^{32}$ See Gottlieb, (2010).

${ }^{33}$ Von Hippel, K.(2010). Poverty is an important cause, In Gottlieb (ed.) Debating terrorism and counter terrorism.SAGE, London.
} 
Krueger and Maleckova $(2003)^{34}$ are concerned that alleviating poverty is reason enough to pressure economically advanced countries to provide more aid than they are currently giving, creating perverse incentives for some groups to engage in terrorism. The more recent ISIS crisis has been used as a reference to this poverty-terrorism debate. For example, President Obama states that "radicalised Muslims are the product of ingrained poverty" followed by the idea that the "barbarism displayed by ISIS could be cured with a job program" (Hohmann, 2015). ${ }^{35}$

However, understanding the causal relationship between poverty, deprivation and terrorism, has been a challenge due to the changing nature of global terrorism. This has been justified by the $9 / 11$ tragedy and subsequent attacks in Indonesia, Spain, Britain, Morocco and Turkey (Piazza, 2010). Smith (2002:37), for example, writes that, 'before the September 11 attacks, experts generally considered suicide bombers to be usually poor, [and] not particularly well-educated' (Groves, 2008) ${ }^{36}$ However, numerous studies and surveys, both prior to and since $9 / 11$ have suggested that people who resort to terrorism are normally far from below the poverty line(Groves, 2008). The 9/11 tragedy has been a crucial event in changing the dominant terrorism discourse, providing greater challenge in understanding the poverty-terrorism relationship in effect, the causes of terrorism have been increasingly ambiguous and many terrorist networks have been proven to originate within a "nonpoverty context', which includes 'money, education and privilege' (Martin-Gorski, 2002). ${ }^{37}$ Hence the idea of poverty, and the claim that terrorism might develop in areas of the world stricken by poverty, needs to be critically assessed as there are a number of other socio-political, geographical and cultural factors involved in radicalising people and enabling an environment for political violence. Blaming poverty, oppression and exclusion may overshadow the serious roots of terrorism in political, cultural and historical contexts. The section below presents some arguments and evidence to justify a negative causality of poverty and terrorism.

\section{NO, TERRORISM IS NOT CAUSED BY POVERTY, OPPRESSION AND EXCLUSION}

"The bottom line...is that poor economic conditions do not seem to motivate people to participate in terrorist activities"

(Krueger, 2007:12)

The event of September 11, 2001, taught us that weak states, like Afghanistan, can pose as great a danger to our national interests as strong states. Poverty does not make poor people into terrorists and murderers. Yet, poverty, weak institutions and corruption can make weak states vulnerable to terrorist networks and drugs cartels within their borders"38

These statements are quite surprising for those who argue for and believe poverty is a root cause of terrorism. Referring to scholarly evidence that supports this negative causality, Sterman (2015) explains that a study of terrorism in 96 countries between 1986 and 2002, showed 'no' link between economic measures and terrorism. He refers to Krueger and Maleckova'sjustification for Hezbollah and Hamas, which suggests that upper class and more educated individuals are slightly overrepresented among terrorists because terror groups actively select for those individuals from large populations of potential recruits. Sageman $(2004)^{39}$ explains that three-quarters of Al Qaeda members are from upper and middle class backgrounds, and a majority have a university education, concluding that 'these are the best and brightest of their societies in many ways'.Referring to the separatist movement in Turkey, Derin-Gúre and Elveren $(2013)^{40}$ suggest that income inequality, which is an essential factor of economic deprivation, is not a main cause of the escalation of separatist terrorism in Turkey. They argue that poverty is one crucial 'persisting' factor that contributes to the sustainment of

\footnotetext{
${ }^{34}$ Krueger, A B. \& Maleckova, J. (2003), Education, Poverty And Terrorism: Is There A Causal Connection?, Journal of Economic Perspectives, 2003, Vo1, 7(4), 119-144.

${ }^{35}$ Hohmann L, Shock reaction to Obama's poverty causes terror: Retrieved from, http:// www.wnd.com/ 2015/02/ shock-reaction-to-obamas-poverty-causes-terror-meme/

36 Grove. A.(2008), Discuss and Evaluate the relationship between poverty and terrorism:Retrieved from,http://www.e-ir.info/2008/01/04/discuss-and-evaluate-the-relationship-between-poverty-and-terrorism/

${ }^{37}$ Martin-Gorski (2002),Is poverty a root cause of terrorism? Retrieved from,- http://ontology.buffalo.edu/smith/ courses01/papers/Martin_Gorski.pdf

${ }^{38}$ National Security Strategy of the Bush Administration: Retrieved from, http://www.state.gov/documents/ organization/63562.pdf

${ }^{39}$ Sageman, M (2004), 'Understanding Terror Networks', FPRI Situation Report on the War on Terrorism

${ }^{40}$ Derin-Gúre, P., \& Elveren A., Y. (2013). Does income inequality derive the separatist terrorism in Turkey?
} 
separatist terrorism in Turkey.

Alan Krueger's (2007) discussion on what makes a terrorist, provides a concise analysis by challenging the popular wisdom that economic powerlessness - poverty and deprivation, and inadequate education are the root causes of terrorism. Krueger criticises prominent and wellintentioned scholars, world leaders and religious figures by writing that "uneducated, impoverished masses are particularly 'unlikely' to participate in the political process through either legitimate or illegitimate means" (2007:3). Terrorism is purely motivated by geopolitical grievances, not desperation and, as Krueger writes, "the West is often a target - not because it is rich, but because it is influential and because terrorism has a greater chance of succeeding when it is perpetrated against a democracy than an autocracy" (2007:4). According to Krueger and Maleckova (2003), the connection between poverty, education and terrorism is indirect, complicated and probably quite weak. Instead of suggesting terrorism as a direct response to low market opportunities or ignorance, they suggest that it is more accurately viewed as a response to political conditions and long-standing feelings of indignity and frustration that have little to do with economics. Martin-Groski (2002), for instance, provides some empirical evidence justifying the view that poverty is not a root cause of terrorism. He provides some examples of typical Islamic militants in Egypt, who are from "the middle, or lower-middle-class with high achievement and motivation, upwardly mobile, with science or engineering education. In Turkey, 25 percent of the members of an Islamic militant party are engineers; Bangladesh, Yemen and Niger, which are three of the poorest Muslim countries, have not become hotbeds of militant Islam.

Piazza (2010) provides a compelling analysis by pinpointing weaker aspects of the poverty - terrorism debate, and discusses other possible root causes of terrorism that merit more attention. Based on international statistics on poverty and political violence, Piazza explains that 'changes of global terrorism rates are out of sync with changes in global poverty rates and measurements of global inequality, which do not show cyclical dynamics' (2010:39). If we think, poverty is the root cause of terrorism, it would be reasonable to expect that poorer regions would experience the most terrorism and would produce a greater number of terrorists than wealthier nations, which is not the case (2010:41). Referring to the ten poorest countries in the world ${ }^{41}$, Piazza argues that though many of these countries have experienced civil wars, terrorism has not been a major issue in their lists of security challenges. Guinea Bissau, Mozambique and Central African Republic, for example, have no experienced or produced terrorism whatsoever during the period 2000-2006. It is interesting to note that in 2007, Sri Lanka, the Philippines, Georgia, Venezuela and Uzbekistan were amongst the countries with the fastest-growing significant terrorism challenges.

Weak political rights are significantly linked with higher levels of terrorism, and countries with higher levels of political rights suffer the lowest levels of terrorism (Abadie,2006). ${ }^{42}$ The real cause of terrorism, as Ahmed $(2015)^{43}$ writes, is not related to poverty but to anger. Ahmed refers to some evidence from former militants in Afghanistan, Somalia and Colombia to explain the reasons for joining violent extremist groups. 'I did not join the Taliban because I was poor, I joined because I was angry'. Why angry? 'Because the Islamic school was destroyed. It was where the young people studied. It was the centre of my village'. In this context, poverty becomes insignificant as concrete grievances exist among an identifiable subgroup of a larger population and there is a lack of opportunities for political participation (Crenshaw, 1981). When young people do not enjoy meaningful opportunities in their lives, and are alienated from the societies around them, and when they have grievances that go unaddressed, they are going to be more at risk of joining terrorist movements (Ahmed, 2015).

However, if we accept the broad findings of these analyses, where does this leave the relationship between poverty and terrorism? The relationship between poverty and other factors (political, cultural and historical) and terrorism still remains complex and ambiguous. Although the above evidence does not fully comfort either side, causality between poverty and terrorism has been an attractive option

\footnotetext{
${ }^{41}$ The ten poorest countries based on HDI in 2005- Sierra Leone (poorest), Burkina Faso, Guinea Bissau, Niger, Mali, Central African Republic, Mozambique, Chad, Ethiopia and Congo.

${ }^{42}$ Abadie, A. (2006). Poverty, political freedom and the roots of Terrorism: Retrieved from, http://www. hks.harvard.edu/fs/aabadie/povterr.pdf

${ }^{43}$ Ahmed, B. (2015), What's the real cause of terrorism, poverty or anger?. Retrieved from http:// thinkprogress.org/world/2015/02/19/3624543/economics-of-terrorism/
} 
giving policymakers a cogent tool in the fight against terrorism while promoting economic development. But poverty has never derailed or demoralised the political dynamics and political motivations of terrorism. The remainder of this essay discusses possible approaches towards a critical understanding of the poverty-terrorism relationship.

\section{DisCuSSION AND CONCLUSION}

As revealed in the discussion, it is rather likely there are multiple causes of terrorism, some of which might involve poverty, oppression and exclusion and some of which might not. Poverty and terrorism do not represent a positive causality, and empirical analyses often fail to yield a distinct relationship between them (Piazza, 2010). Given the fact that poverty is not a root cause of terrorism, there is no direct evidence with which to prosecute 1.2 billion poor people as terrorists. How could it be claimed one third of the world poorest people, who live in India, are terrorists? Referring to the povertyterrorism debate Huesmann and Huesmann (2012) ask, are poverty and exclusion necessary for terrorism? Are they sufficient causes of terrorism? Can poverty and exclusion contribute partially to causing terrorism? (In Jackson et al, 2012). ${ }^{44}$ Were poverty and exclusion crucial factors in forming Al-Qaeda, Hamas, IRA, and LTTE, for example? What is terrorism, why, how and when it occurs are simple, but rational questions to be examined for critical understanding of the causes of terrorism. A coherent answer is often obscured by erratic and diverse manifestations of terrorism, and more importantly by the structures - social, political, economic, including cultural conditions that shape and limit the choices that human agents make, thereby predetermining terrorist behaviours. The spatiality of terrorism, which involves the time, place and context/space, where terrorism originates, is different. Therefore, in reality, terrorism is multi-causal and it has multidirectional relationships with its causes.

This complexity is explained by Piazza, referring to the Sri Lankan context as an example. He asked, "is terrorism in a poverty-stricken area like underdeveloped northern Sri Lanka prompted and sustained by a poor level of local economic development or have thirty years of brutal attacks by Tamil separatists eroded local economic progress and increased poverty by scaring away investment?" (2010:50). This demonstrates a fundamental structural problem in our methods and approach towards understanding the 'causes' and relationship between poverty and terrorism. When the data is aggregated in a broader analysis of the causes of terrorism, the poverty-related routes become less visible, but that does not mean they do not exist. Sterman (2015) argues that although scholars carefully acknowledge this limitation, pundits have side lined it in grand pronouncements that poverty does not cause terrorism.

By referring to the above point, I see two types of poverty: absolute poverty, which I define as monetary poverty, lack of 'financial assets' for fulfilling basic necessities - food, shelter and cloths; and social poverty, an extreme condition that involves 'relatively' limited choices, opportunities and freedom, insecurity, powerlessness and exclusion. Seeing poverty as a form of socio-economic and political exclusion, rather than simply as a lack of financial resources, may have important consequence for terrorism analysis and, specifically, in understanding the 'relationship' between poverty and terrorism. Poverty, rather than a cause, can be studied as a facilitator of terrorism providing moral justifications for the frustrations and anger that lead to violent behaviour and to terrorism. For example, justifying the Islamic Resistance Movement, the leader of Hamas proclaims that it is enough to see the poverty stricken outskirts of Algiers or the refugee camps in Gaza to understand the factors that nurture the strength of the movement (Pipes, 2002). ${ }^{45}$ Poverty has been remained as an important factor 'behind' terrorism. As with many other phenomena, poverty has also been manipulated as a 'tool' for justifying 'terrorism', but not the 'terrorist'. Terrorists are not poor; they are upper and middle class, a skilful and educated group that uses poverty to 'urge' the individual to act on behalf of the majority. Hence, poverty plays an important role in strengthening terrorist tactics, by drawing support from the excluded groups (as recruits). For example, LTTE in Sri Lanka was strengthened by recruiting poor members of the community and urging that their fight was for their own liberation from oppression and marginalization. In such a context, it is important to note the possibility that support for terrorism may not be a consequence of poverty itself, but rather a consequence of political instability as well. In effect, it may be less ambiguous if we understand

\footnotetext{
${ }^{44}$ Jackson, R., \& Sinclair, S., (2012). Contemporary Debates on Terrorism, Routledge, New York.

${ }^{45}$ Pipes, D, (2002) 'God and Mammon: Does Poverty Cause Militant Islam?', National Interest, Winter Edition,
} 
poverty as a persistent factor of terrorism rather than a founding factor. Without doubt poverty enables terrorism, and as Krueger suggests, better education and combating poverty might be a part of the solution, but he also warns that, "incorrectly linking poverty and terrorism can be counterproductive to our efforts to reduce the former even as we confront the latter" (2007:52).

That 'poverty causes terrorism' is a popular myth created in the wake of the $9 / 11$ attacks and this notion has largely been criticised by terrorism researchers, but it continuous to be propounded by politicians. In reiterating the link between poverty and terrorism, politicians benefit from increased development aid, which in turn reinforces terrorism. Core-peripheral interdependency and the globalisation process make poverty inescapable for poorer nations, often resulting terrorism and internal conflicts. Criticising this process, Brynjar and Skjølberg (2004) argue that poverty becomes structural and leads to 'predatory and praetorian' political systems, 'which in turn fosters endemic social unrest and civil violence' (In Groves, 2008). Although many scholarly arguments and international politics attempt to justify poverty as a cause of terrorism, it is not true. It may be true that poverty creates conditions favorable for terrorism. Along with these conditions, there are other circumstances that, in combination, provoke some people to see terrorism as an effective way of creating change in their world. Therefore, it is important to understand the causes of terrorism to be able to craft effective counter-terrorism measures, but false judgements and an unjustified connection between poverty and terrorism carries the risk that the international community may lose interest in helping poor nations leaving them to suffer (see Krueger \& Maleckova, 2003). 